\title{
PENGARUH HARGA DAN KUALITAS PELAYANAN SERTA KUALITAS PRODUK TERHADAP KEPUASAN KONSUMEN PADA BAKSO PAK MIAD KECAMATAN TAMAN KABUPATEN PEMALANG
}

\author{
Dani Agung Wicaksono" ${ }^{1)}$, Trias Ayu Laksanawati ${ }^{2)}$, Dwi Budian Ningsih' ${ }^{3)}$ \\ ${ }^{1,2,3)}$ Politeknik Negeri Banyuwangi, Prodi D-IV Teknologi Pengolahan Hasil Ternak \\ Email : dani@poliwangi.ac.id
}

\begin{abstract}
The meatball stall which is a typical dish from Pemalang is Pak Miad's meatball. Pak Miad's meatball stall is the pioneer of meatball traders in Pemalang because it has been established since 1967. Pak Miad's meatball stall is famous for its different shape from meatballs in general. The purpose of this study was to determine the effect of price and service quality and product quality on consumer satisfaction at Pak Miad's meatballs in Taman Subdistrict, Pemalang Regency by proposing five hypotheses. Quantitative research used in this research. The sample obtained was 100 respondents using purposive sampling technique using Multiple Linear Regression data analysis which included validity and reliability tests, classical assumption test, multiple linear regression analysis, testing through $t$ test and $F$ test, and coefficient of determination $(R 2)$ test. The results showed that the service quality variable had no significant effect on customer satisfaction. Product quality variable has a significant effect on consumer satisfaction and product quality is the variable that has the most dominant influence on consumer satisfaction.
\end{abstract}

Keywords: Price, Service Quality, Product Quality and Consumer Satisfaction

\begin{abstract}
Abstrak
Warung bakso yang menjadi kuliner khas dari Pemalang yaitu bakso Pak Miad. Warung bakso Pak Miad ini menjadi pelopor pedagang bakso yang ada di Pemalang karena telah berdiri sejak tahun 1967. Warung bakso Pak Miad terkenal karena bentuk baksonya berbeda dengan bakso pada umumnya. Riset ini bertujuan untuk mengetahui pengaruh harga dan kualitas pelayanan serta kualitas produk terhadap kepuasan konsumen pada bakso Pak Miad di Kecamatan Taman Kabupaten Pemalang dengan mengajukan lima hipotesis. Penelitian kuantitatif di pakai pada riset ini. Sampel yang diperoleh berjumlah 100 responden dengan teknik purposive sampling menggunakan data analisis Regresi Linier Berganda yang mencakup uji validitas dan reliabilitas, uji asumsi klasik, analisis regresi linier berganda, pengujian hipotesis melalui uji $t$ dan uji $F$, serta uji koefisien determinasi $\left(R^{2}\right)$. Hasil penelitian menunjukkan bahwa Variabel kualitas pelayanan tidak berpengaruh signifikan terhadap kepuasan konsumen. Variabel kualitas produk berpengaruh signifikan terhadap kepuasan konsumen serta kualitas produk menjadi variabel yang berpengaruh paling dominan terhadap kepuasan konsumen.
\end{abstract}

Kata kunci : Harga, Kualitas Pelayanan, Kualitas Produk dan Kepuasan Konsumen

\section{Pendahuluan}

Kecamatan di Kabupaten Pemalang salah satunya adalah Kecamatan Taman yang memiliki luas wilayah $67.41 \mathrm{~km}^{2}$ dan terbagi menjadi 21 desa (BPS Pemalang, 2021). Kuliner yang ada di kecamatan Taman sangat beragam salah satunya bakso. Jumlah warung bakso yang ada di kecamatan Taman kurang lebih sebanyak 200 warung. Warung bakso yang menjadi kuliner khas dari Pemalang yaitu bakso Pak Miad. Warung bakso Pak Miad terletak di Jalan Bale Kambang 1 Kelurahan Jebed Utara Kecamatan Taman Kabupaten Pemalang. Letaknya dekat 


\section{Vol. 2 No. 2 Bulan Oktober 2021 - Maret 2022}

dengan pusat kota Pemalang hanya berjarak tempuh sekitar 7,4 km.Warung bakso Pak Miad ini menjadi pelopor pedagang bakso yang ada di Pemalang karena telah berdiri sejak tahun 1967.

Persaingan kuliner pada sekarang ini semakin mengetat, setiap pelaku usaha diharapkan untuk mampu bersaing dan Mencoba membuat produk yang memiliki manfaat serta tidak menyerupai dengan produk pesaing, persaingan ini tidak dapat dihindarkan lagi oleh usaha dengan cakupan yang sangat besar maupun terbatas (Utomo, 2010). Agar mampu tetap eksis ditengah maraknya kompetitif kuliner yang telah bermunculan, pelaku usaha wajib menciptakan strategi yang cenderung tertuju kepada konsumen yaitu menciptakan kepuasan konsumen. Kepuasan konsumen adalah kondisi di mana konsumen mampu merasakan kegunaan yang disajikan oleh hasil olahan tersebut dan sejalan dengan apa yang diinginkan (Rustanti 2015). Adabeberapa indikasi yang dapat berpengaruh terhadap kepuasan konsumen yaitu harga, kualitas pelayanan dan kualitas produk (Putro, 2014). Dari uraian tersebut, peneliti merumuskan tujuan dalam penelitian ini yaitu menguji pengaruh harga dan kualitas pelayanan serta kualitas produk secara simultan dan parsial terhadap kepuasan konsumen bakso Pak Miad di Kecamatan Taman Kabupaten Pemalang.

\section{Tinjauan Pustaka}

Harga merupakan suatu unsur yang menghasilkan pendapatan dari bauran pemasaran (Kotler dan Keller, 2007). Konsumen melakukan pembelian hal yang diperhatikan yaitu harga. Konsumen harus menggelontorkan biaya yang lebih banyak untuk suatu produk disandingkan dengan kegunaan yang diperoleh, maka konsumen akan menganggap bahwa produk tersebut memiliki nilai negatif dan memberikan nilai yang buruk serta memangkas pemakaian terhadap produk tersebut. Namun, apabila kegunaan yang diperoleh pemakai lebih besar, maka produk tersebut mempunyai nilai positif dan menjadikan konsumen untuk membeli ulang (Lupiyoadi, 2006).

Kualitas pelayanan adalah kontrol antara tingkat pelayanan organisasi dan asumsi pembeli. Kualitas pelayanan dibuat untuk mengatasi permasalahan serta keinginan pembeli dan memenuhi atau melampaui asumsi pelanggan (Tjiptono et al., 2012). Kualitas pelayanan merujuk kepada penilaian pembeli terhadap kualitas bisnis. Semakin baik layanan yang diberikan akan mempengaruhi tingkat loyalitas konsumen sehingga usaha tersebut dipandang semakin 


\section{Vol. 2 No. 2 Bulan Oktober 2021 - Maret 2022}

baik. Kemudian lagi, dengan asumsi bahwa layanan yang diberikan tidak dapat diterima, bisnis akan dinilai berkualitas rendah. Selanjutnya, sifat pelayanan harus terus dibenahi untuk meningkatkan kualitas bisnis.

Kualitas Produk sesuai dengan penetapan atau pedoman yang ditetapkan oleh klien, untuk situasi ini asumsi klien. Semakin tinggi keakuratan produk, semakin tinggi kualitas barang dan semakin tinggi loyalitas pelanggan. Tujuan klien yang terpenuhi akan mempengaruhi loyalitas pelanggan, yang selanjutnya akan mengembangkan kinerja organisasi (Hartini, 2012).

Alasan seorang pebisnis melaksanakan usahanya adalah untuk membuat pembeli merasakan kepuasan terhadap produk yang kita tawarkan, sehingga perhatian terhadap pemenuhan dan pembelian semakin besar. Semakin tinggi loyalitas konsumen, semakin diperhatikan manfaat bagi pelaku bisnis dan membuat pembeli membeli kembali barang tersebut. Namun, jika tingkat kepuasan pembeli sedikit, pembeli ini akan beralih ke produk pesaing. Kepuasan dapat di terjemahkan dengan bahasa tingkat kepuasan seseorang setelah dibandingkan dengan apa yang dirasakan denga apa yang diharapakan (Kotler, 2000).
Mengacu pada landasan teori diatas, maka dapat diilustrasikan kerangka konseptual pada riset ini:

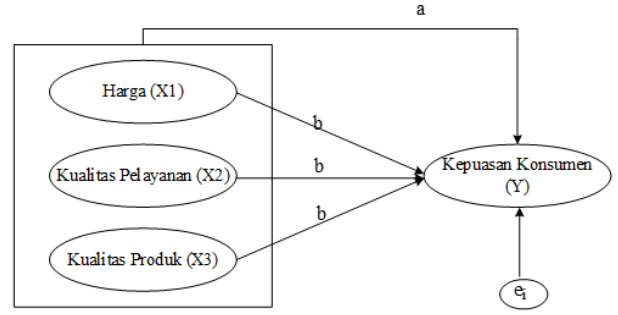

\section{Gambar 1. Kerangka Konseptual}

Keterangan pengaruh:

a : simultan

b : parsial

Hipotesis yang dapat ditarik dalam kerangka konseptual di atas yaitu:

a. Variabel harga dan kualitas pelayanan sertakualitas produk secara simultan berpengaruh signifikan terhadap kepuasan konsumen bakso Pak Miad di Kecamatan Taman Kabupaten Pemalang

b. Variabel harga secara parsial berpengaruh signifikan terhadap kepuasan konsumen bakso Pak Miad di Kecamatan Taman Kabupaten Pemalang

c. Variabel kualitas pelayanan secara parsial berpengaruh signifikan terhadap kepuasan konsumen bakso Pak Miad di Kecamatan Taman Kabupaten Pemalang

d. Variabel kualitas produk secara parsial berpengaruh signifikan terhadap kepuasan konsumen bakso Pak Miad di Kecamatan Taman Kabupaten Pemalang 
e. Variabel kualitas produk berpengaruh paling dominan terhadap kepuasan konsumen bakso Pak Miad di Kecamatan

Taman Kabupaten Pemalang

\section{Metode Penelitian}

Riset ini menggunakan pendekatan kualitatif yang dikuantitatifkan. Pada penelitian ini variabel yang diteliti merupakan variabel kualitatif sementara jenis data yang yang diperlukan adalah data kuantitatif sehingga Riset ini menggunakan data berupa data kualitatif yang dikuantitatifkan. Proses pengolahan data menggunakan skala likert dan data diwujudkan dalam bentuk angka dan dianalisis lebih lanjut menggunakan IBM SPSS Statistic 25. Penelitian ini terdiri atas tiga variabel, yaitu harga dan kualitas pelayanan serta kualitas produk sebagai variabel bebas (independent) dan kepuasan konsumen sebagai variabel terikat (dependent).

populasi yang akan digunakan dalam penelitian ini adalah konsumen bakso Pak Miad. Dengan sampel 100 orang diambil dengan teknik sampling purposive. Dengan itu sampel yang digunakan harus sesuai dengan syarat-syarat yang telah ditentukan seperti:

a. Konsumen yang berada di warung bakso daging Pak Miad. b. Usia minimal 17 tahun.

c. Minimal sudah pernah berkunjung ke warung bakso daging Pak Miadsebanyak 2 kali.

\section{Hasil Penelitian dan Pembahasan}

\subsection{Hasil Penelitian}

Uji validitas dilaksanakan dengan memakai korelasi Product Moment (Pearson). Pada uji validitas ini, barometer suatu nilai dinyatakan valid jika $\mathrm{r}_{\text {hitung }}$ lebih besar dari $r_{\text {tabel. }}$ Pada uji validitas ini diketahui n adalah 100 dan $a=5 \%$, maka $\mathrm{r}_{\text {tabel(5\%,100-2) }}$ $=0,196$. Setiap item dikatakan valid jika lebih besar dari 0,196. Bersumber dari hasil tabel 1. Maka dinyatakan valid.

\begin{tabular}{|c|c|c|c|c|}
\hline Variabel & Item & $\mathrm{r}_{\text {hane }}$ & Sig. & Ket. \\
\hline \multirow{8}{*}{ Harga } & $\mathrm{X} 1.1$ & 0,536 & 0,000 & Valid \\
\hline & $\mathrm{X} 1.2$ & 0.672 & 0.000 & Valid \\
\hline & $\mathrm{X} 1.3$ & 0,589 & 0,000 & Valid \\
\hline & $\mathrm{X} 1.4$ & 0,611 & 0,000 & Valid \\
\hline & $\mathrm{X} 1.5$ & 0,588 & 0,000 & Valid \\
\hline & $\mathrm{X} 1.6$ & 0,462 & 0,000 & Valid \\
\hline & $\mathrm{X} 1.7$ & 0,634 & 0,000 & Valid \\
\hline & $\mathrm{X} 1.8$ & 0.584 & 0.000 & Valid \\
\hline \multirow{8}{*}{$\begin{array}{l}\text { Kualitas } \\
\text { Pelayanan }\end{array}$} & $\mathrm{X} 2.1$ & 0,519 & 0,000 & Valid \\
\hline & $\mathrm{X} 2.2$ & 0,639 & 0,000 & Valid \\
\hline & $\mathrm{X} 2.3$ & 0,606 & 0,000 & Valid \\
\hline & $\mathrm{X} 2.4$ & 0,591 & 0,000 & Valid \\
\hline & $\mathrm{X} 2.5$ & 0,647 & 0,000 & Valid \\
\hline & X2.6 & 0.524 & 0,000 & Valid \\
\hline & X2.7 & 0,568 & 0,000 & Valid \\
\hline & $\mathrm{X} 2.8$ & 0,619 & 0,000 & Valid \\
\hline \multirow{8}{*}{$\begin{array}{l}\text { Kualitas } \\
\text { Produk }\end{array}$} & $\mathrm{X} 3.1$ & 0,591 & 0,000 & Valid \\
\hline & $\mathrm{X} 3.2$ & 0,616 & 0,000 & Valid \\
\hline & X3.3 & 0,595 & 0,000 & Valid \\
\hline & X3.4 & 0,381 & 0.000 & Valid \\
\hline & $\mathrm{X} 3.5$ & 0,583 & 0,000 & Valid \\
\hline & $\mathrm{X} 3.6$ & 0,556 & 0,000 & Valid \\
\hline & $\mathrm{X} 3.7$ & 0,641 & 0,000 & Valid \\
\hline & $\mathrm{X} 3.8$ & 0,595 & 0,000 & Valid \\
\hline \multirow{8}{*}{$\begin{array}{l}\text { Kepuasan } \\
\text { Konsumen }\end{array}$} & Y1 & 0,752 & 0,000 & Valid \\
\hline & $\mathrm{Y} 2$ & 0,738 & 0.000 & Valid \\
\hline & Y3 & 0,718 & 0,000 & Valid \\
\hline & Y4 & 0,772 & 0,000 & Valid \\
\hline & Y5 & 0,562 & 0,000 & Valid \\
\hline & Y6 & 0,685 & 0,000 & Valid \\
\hline & Y7 & 0,623 & 0,000 & Valid \\
\hline & Y8 & 0,385 & 0.000 & Valid \\
\hline
\end{tabular}

Sumber : Data yang diolah penulis, 2021

Tabel. 1 Uji validitas 
Uji reliabilitas ini dilakukan dengan menggunakan Cronbach Alpha. Dalam uji reliabilitas, suatu instrumen penelitian dapat diterima bila dalam kisaran Cronbach Alpha $>$ 0,60 dianggap baik atau reliabel adapun tabel hasil uji reliabilitas adalah sebagai berikut :

\begin{tabular}{ccc}
\hline Variabel & Nilai Alpha & Keterangan \\
\hline Harga & 0,721 & Reliabel \\
\hline Kualitas Pelayanan & 0,730 & Reliabel \\
\hline Kualitas Produk & 0,701 & Reliabel \\
\hline Kepuasan kons. & 0,815 & Reliabel \\
\hline
\end{tabular}

Sumber : Data yang diolah penulis, 2021

\section{Tabel 2. Uji Reliabilitas}

Tabel diatas menunjukkan bahwa hasil pengujian reliabilitas semua variabel menghasilkan nilai Cronbach Alpha lebih besar dari 0,60 atau 60\%, sehingga dapat diartikan bahwa semua item peryataan pada setiap variabel dalam penelitian ini reliabel dan dapat diuji lanjut.

Analisis regresi linier berganda digunakan untuk mengetahui pengaruh harga dan kualitas pelayanan serta kualitas produk terhadap kepuasan konsumen. Hasil pengolahan data didapatkan persamaan regresi sebagai berikut:

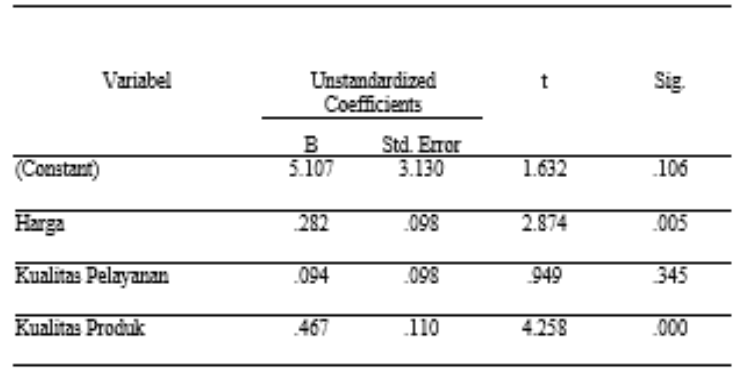

Sumber : Data yang diolah penulis, 2021

\section{Tabel 3. Regresi inier Berganda}

Variabel dependent pada model regresi linier berganda ini adalah kepuasan konsumen (Y) sedangkan variabel independent adalah variabel harga $\left(\mathrm{X}_{1}\right)$ dan kualitas pelayanan $\left(\mathrm{X}_{2}\right)$ dan kualitas produk $\left(\mathrm{X}_{3}\right)$. Model regresi berdasarkan hasil analisis di atas adalah :

$Y=5,107+0,282 X_{1}+0,094 X_{2}+0,467 X_{3}$

Keterangan :

$\mathrm{X}_{1}$ : Harga

$\mathrm{X}_{2}:$ Kualitas Pelayanan

$\mathrm{X}_{3}:$ Kualitas Produk

Y : Kepuasan Konsumen

Berdasarkan output SPSS, nilai $\mathrm{R}$ Square adalah sebesar 0,442 atau 44,2\%. Artinya besarnya pengaruh harga, kualitas pelayanan dan kualitas produk secara simultan sebesar $44,2 \%$, sedangkan sisanya $55,8 \%$ dipengaruhi oleh faktor lain diluar model seperti faktor citra merek, promosi, lokasi dan lain sebagainya yang perlu diteliti selanjutnya. 
Uji normalitas digunakan untuk menguji apakah nilai residual yang telah dilakukan pada model regresi berdistribusi normal atau tidak normal. Uji normalitas pada penelitian ini menggunakan pendekatan normal P-P (plot of regression standardized residual) dengan syarat jika data menyebar disekitar garis diagonal dan mengikuti arah garis diagonal maka data tersebut dinyatakan normal, jika sebaliknya data tidak menyebar disekitar garis diagonal maka data tidak normal. Berdasarkan hasil pengujian diperoleh hasil sebagai berikut :

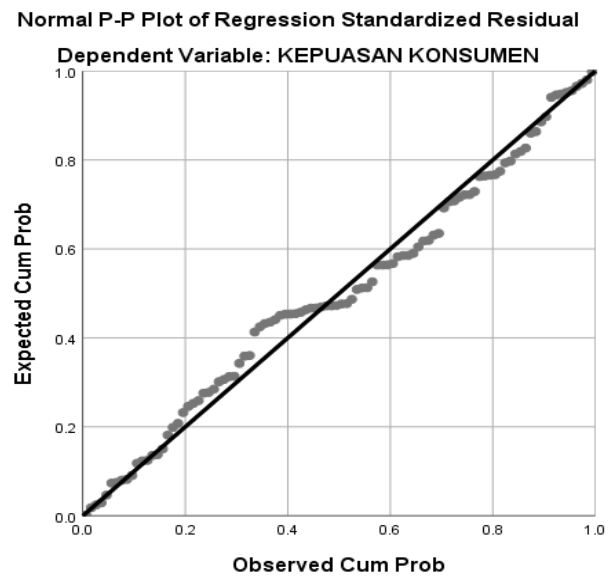

\section{Gambar 2. Hasil Uji Normalitas}

Berdasarkan grafik diatas, dapat disimpulkan bahwa model regresi memenuhi asumsi normalitas karena data menyebar di sekitar garis diagonal dan mengikuti garis diagonal tersebut.

Uji multikolinieritas yaitu pengujian untuk melihat apakah antar variabel bebas dari model regresi terdapat korelasi atau tidak, jika nilai toleransi $>0,1$ dan VIF $<10$ maka tidak terjadi gangguan multikolinieritas, tetapi apabila nilai toleransi $<0,1$ dan VIF $>10$ maka terjadi gangguan multikolinieritas.

\begin{tabular}{cccc}
\hline Variabel & Tolerance & VIF & Keterangan \\
\hline Harga & 0,647 & 1,546 & $\begin{array}{c}\text { Bebas } \\
\text { Multikolinieritas }\end{array}$ \\
\hline $\begin{array}{c}\text { Kualitas } \\
\text { Pelayanan }\end{array}$ & 0,542 & 1,847 & \\
\hline $\begin{array}{c}\text { Kualitas } \\
\text { Produk }\end{array}$ & 0,615 & 1,627 & \\
& & & \\
\hline
\end{tabular}

Sumber : Data yang diolah penulis, 2021

Tabel 4. Uji Multikoliniearitas

Berdasarkan tabel diatas, diperoleh nilai tolerance dari variabel harga $0,647>0,1$ dan VIF 1,546 < 10, kualitas pelayanan 0,542 $>0,1$ dan VIF 1,847 < 10, dan kualitas produk $0,615>0,1$ dan VIF 1,627 < 10 . Maka dapat disimpulkan bahwa korelasi antar variabel bebas menunjukan tidak ada gangguan multikolinieritas.

Pengujian heteroskedastisitas pada penelitian ini dideteksi dengan menggunakan uji Glejser. Uji Glejser digunakan dengan meregresikan antara variabel independent dengan nilai absolute residualnya. Jika nilai signifikansi antara variabel independent dengan absolute residual > 0,05 maka tidak terjadi masalah heteroskedastisitas. 


\begin{tabular}{cccc}
\hline Variabel & thinug & Sig. & Keterangan \\
\hline Harga & $-0,483$ & 0,630 & $\begin{array}{c}\text { Bebas } \\
\text { Heterokedastisitas }\end{array}$ \\
\cline { 1 - 3 } $\begin{array}{c}\text { Kualitas } \\
\text { Pelayanan }\end{array}$ & $-0,758$ & 0,450 & \\
& & & \\
\cline { 1 - 2 } $\begin{array}{c}\text { Kualitas } \\
\text { Produk }\end{array}$ & 1,293 & 0,199 & \\
\hline
\end{tabular}

Sumber : Data yang diolah penulis, 2021

\section{Tabel 5. Uji heteroskedastisitas}

Berdasarkan data yang telah diolah dengan menggunakan uji glejser dapat diketahui tidak terjadi heterokedastisitas karena nilai signifikansi dari masing-masing variabel independent $>0,05$ dengan demikian dapat disimpulkan bahwa tidak terjadi heteroskedastisitas.

\subsection{Pembahasan}

Nilai koefisien determinasi ( $R$ Square) sebesar 0,442, dapat dinyatakan bahwa kepuasan konsumen Warung Bakso Pak Miad ditentukan 44,2\% oleh variabel harga, kualitas pelayanan dan kualitas produk, selebihnya $55,8 \%$ dipengaruhi oleh variabel lain. Masih mengacu pada hasil penelitian uji simultan didapati Harga, Kualitas Pelayanan Dan Kualitas Produk secara simultan berpengaruh terhadap Kepuasan Konsumen Warung Bakso Pak Miad yang berarti $\mathrm{H}_{1}$ diterima. Penelitian ini didukung oleh peneliti Agustin (2016), Cahyani dan sitohang (2016), sari (2016), Aulia dan
Hidayat (2017), Kurniawati dan Prasodjo (2019) dan Maimunah (2020).

Keluaran uji hipotesis membuktikan bahwa harga warung bakso Pak Miad berpengaruh positif dan signifikan terhadap kepuasan konsumen. Berdasarkan hasil tersebut harga produk warung bakso Pak Miad dinilai terjangkau oleh konsumen dan konsumen merasa puas dengan warung bakso Pak Miad tersebut. Penelitian serupa juga mendapatkan hasil yang mirip yaitu Arumsari dan Khasanah (2012) Umami dan Sumartik (2019).

Untuk hasil kualitas pelayanan warung bakso Pak Miad tidak berpengaruh positif dan signifikan terhadap kepuasan konsumen. Hal ini dimungkinkan lokasi Warung Bakso Pak Miad yang terletak dipinggir jalan dan menjadikan tempat parkir yang kurang memadai. Untuk menciptakan kualitas pelayanan dengan harapan yang sesuai konsumen, maka bisa dilakukan dengan menambahkan lahan parkiran yang lebih luas. Hal ini bukan berarti variabel kualitas pelayanan tidak berpengaruh, tetap memiliki pengaruh akan tetapi tidak signifikan. Sehingga harus ada poin yang diperbaiki supaya kedepannya mampu memiliki pengaruh yang lebih signifikan. Hasil penelitian ini tidak selaras dengan beberapa penelitian sebelumnya yaitu Aulia dan 
hidayat (2017), Cahyani dan Sitohang (2016), Haromain dan Suprihhadi (2016).

Hasil uji hipotesis membuktikan bahwa variabel kualitas produk pada Warung Bakso Pak Miad berpengaruh positif dan signifikan terhadap kepuasan konsumen. Sedangkan hasil uji analisis regresi linier berganda menunjukkan dari tiga variabel bebas yang terdiri dari Harga $\left(\mathrm{X}_{1}\right)$, Kualitas Pelayanan $\left(\mathrm{X}_{2}\right)$, dan Kualitas Produk $\left(\mathrm{X}_{3}\right)$, dapat diketahui bahwa variabel Kualitas Produk mempunyai nilai beta terbesar yaitu 0,414 yang merupakan nilai terbesar diantara variabel bebas yang lain, sehingga variabel bebas yang berpengaruh dominan terhadap variabel terikat Kepuasan Konsumen adalah variabel Kualitas Produk.

\section{Kesimpulan dan Saran}

\subsection{Kesimpulan}

Hasil riset yang sudah dilaksankan dengan topik ulasan pengaruh harga dan kualitas pelayanan serta kualitas produk terhadap kepuasan konsumen pada bakso Pak Miad di Kecamatan Taman Kabupaten Pemalang dengan memakai sejumlah alat analisis yang dikaitkan dengan hipotesis, dirangkumkan hasil penelitian dibawah ini:

a. variabel harga dan kualitas produk secara parsial berpengaruh signifikan terhadap kepuasan konsumen bakso Pak Miad.
Namun untuk variabel kualitas layanan tidak berpengaruh signifikan. Diantara variabel yang berpengaruh diperoleh varibel kualitas produk merupakan variabel dominan.

b. Diperoleh hasil ketiga variabel bebas berpengaruh secara simultan terhadap kepuasan konsumen bakso Pak Miad. 5.2

\subsection{Saran}

Adapaun saran yang peneliti dapat ajukan adalah :

a. pengaruh paling dominan terhadap kepuasan konsumen yaitu kualitas produk, oleh karenanya diharapkan warung bakso Pak Miad tetap mempertahankan cita rasa produk saat ini. Meningkatkan kualitas pelayanannya dikarenakan hasil uji hipotesis tidak berpengaruh signifikan dengan memperluas tempat parkir karena intensitas pengunjung yang datang selalu ramai sehingga tidak mempersempit jalanan umum yang ada di depan warung bakso.

b. Penambahan variabel diperlukan untuk peneliti selanjutnya guna lebih memperdalam kajian mengenai pembahasan ini. 
DAFTAR PUSTAKA

Agustin, S. (2016). Pengaruh harga, kualitas produk dan kualitas pelayanan terhadap kepuasan konsumen kebab kingabi. Jurnal Ilmu dan Riset Manajemen (JIRM), 5(1).

Arumsari, D., \& Khasanah, I. (2012). Analisis pengaruh kualitas produk, harga dan promosi terhadap keputusan pembelian air minum dalam kemasan (AMDK) Merek Aqua (Studi pada Konsumen Toko Bhakti Mart KPRI Bhakti Praja Provinsi Jawa Tengah). (Disertasi). Fakultas Ekonomika dan Bisnis.

Aulia, M., \& Hidayat, I. (2017). Pengaruh Kualitas Produk, Kualitas Pelayanan dan Harga Terhadap Kepuasan Konsumen Amanda Brownies. Jurnal Ilmu dan Riset Manajemen (JIRM), 6(5).

BPSP] Badan Pusat Statistik Pemalang. (2021). Luas WilayahKecamatan Taman. Badan Pusat Statistik Pemalang. Pemalang.

Cahyani, F. G., \& Sitohang, S. (2016). Pengaruh Kualitas Produk, Kualitas Pelayanan Dan Harga Terhadap Kepuasan Konsumen. Jurnal Ilmu dan Riset Manajemen (JIRM), 5(3).

Haromain, I., \& Suprihhadi, H. (2016). Pengaruh Kualitas Layanan, Harga, Dan Lokasi Terhadap Kepuasan Pelanggan di Ahass Z618. Jurnal Ilmu dan Riset Manajemen (JIRM), 5(5).

Hartini, S. (2012). Peran inovasi: pengembangan kualitas produk dan kinerja bisnis. Jurnal Manajemen dan Kewirausahaan (Journal of
Management

and Entrepreneurship), 14(1), 83-90.

Kotler, P. (2000). Marketing Management, Millenium Edition, Prentice Hall Inc. New Jersey.

Kotler, P., \& Keller, K. L. (2007). Manajemen Pemasaran. Edisi Bahasa Indonesia. Jakarta: PT Indeks.

Kurniawati, T., Irawan, B., \& Prasodjo, A. (2019). Analisis Pengaruh Kualitas Pelayanan, Harga, dan Brand Image Terhadap Kepuasan Konsumen Restoran Pizza Hut Cabang Jember. $e$ Journal Ekonomi Bisnis dan Akuntansi, 6(2), 147-151.

Lupiyoadi, H., \& Hamdani, A. (2006). Manajemen Pemasaran Jasa, Edisi Kedua. Jakarta: Penerbit Salemba Empat.

Maimunah, S. (2020). Pengaruh kualitas pelayanan, persepsi harga, cita rasaterhadap kepuasan konsumen dan loyalitas konsumen. IqtishadEOUITY, 1(2)

Putro, S. W. (2014). Pengaruh Kualitas Layanan dan Kualitas Produk Terhadap Kepuasan Konsumen dan Loyalitas Konsumen Restoran Happy Garden. Jurnal Strategi Pemasaran. 2(1), 1-9.

Rustanti, N. (2015). Buku Ajar Ekonomi Pangan dan Gizi.Yogyakarta: CV Bening Utama.

Sari, D. D. (2016). Analisis Pengaruh Kualitas Produk, Kualitas Pelayanan dan Harga Terhadap Kepuasan Konsumen (Studi Kasus Pada Konsumen SIM CARD GSM Prabayar XL di Kota Yogyakarta). Jurnal 
Vol. 2 No. 2 Bulan Oktober 2021 - Maret 2022

Manajemen Bisnis Indonesia (JMBI), 5(1), 62-72.

Tjiptono, F., Chandra, G., \& Adriana, D. (2012). Pemasaran Strategik. Yogyakarta: Andi

Umami, R., \& Sumartik, S. (2019). Pengaruh Kualitas Produk, Harga Dan Kualitas Pelayanan Terhadap Kepuasan Konsumen Kedai Warsu Coffe Cafe. Equilibrium: Jurnal EkonomiManajemen-Akuntansi, 15(2), 250257.

Utomo, T. J. (2010). Lingkungan Bisnis dan Persaingan Bisnis Ritel. Fokus Ekonomi: Jurnal Ilmiah Ekonomi, 5(1). 